Exp. Anim. 56(1), 43-49, 2007

\title{
Carbonic Anhydorase Isoenzyme I (CA-I) Concentration in Feces and Urine as a Temporary Marker of Occult Blood in Beagle Dogs
}

\author{
Kouji IGUCHI ${ }^{1)}$, Katsuhito KAWATO ${ }^{1)}$, Tetsurou SEITA ${ }^{1)}$, Takashi KURIBAYASHI'), \\ Tokihiro SHIMADA ${ }^{1)}$, Mariko MATSUMOTO'), Yutaka YAMAMOTO²), \\ Manabu YAMADA ${ }^{3)}$, and Shizuo YAMAMOTO1)
}

\begin{abstract}
1) Laboratory of Immunology, College of Environmental and Health Sciences, Azabu University, 1-17-71
Fuchinobe, Sagamihara, Kanagawa 229-8501, ${ }^{2)}$ Farm Animal Clinic and Research Center Inc., 3731-1

Kamo, Daisen, Tottori 689-3316, and ${ }^{3}$ Faculty of Life and Environmental Sciences, Prefectural University of Hiroshima, 562 Nanatsuka, Shobara, Hiroshima 727-0023, Japan
\end{abstract}

\begin{abstract}
This study was undertaken to investigate whether the concentration of carbonic anhydorase isoenzyme I (CA-I) in canine feces and urine is useful as a temporary marker of occult blood. Concentrations of CA-I were measured by enzyme-linked immunosorbent assay (ELISA). Fecal CA-I concentrations in 113 healthy beagle dogs (50 male and 63 female) of various ages ranged from 4.3 to $16.7 \mathrm{ng} / \mathrm{g}$ feces (mean; $7.0 \pm 2.9 \mathrm{ng} / \mathrm{g}$ feces). One milliliter of blood from 3 healthy beagle dogs was found to contain 1,047, 1,062 and 1,150 $\mu \mathrm{g}$ CA-I. The fecal CA-I concentrations of dogs receiving intragastric infusions of autologous blood (10 ml) were very low. However, the fecal CA-I concentrations of dogs receiving infusion of autologous blood (5 ml) into the ascending colon were very high. Detection of fecal CA-I would be useful for identifying dogs with hemorrhaging of the large intestine. Of 55 urinary samples collected from healthy beagle dogs by catheter, chemical tests for occult blood were negative in 44, but CA-I concentrations ranged from 1.8 to $12.6 \mathrm{ng} / \mathrm{ml}$ (mean; $6.9 \pm 5.4 \mathrm{ng} / \mathrm{ml}$ ) by ELISA. The CA-I concentrations of the other 11 samples, which tested positive for occult blood on chemical testing, ranged from 41.2 to $525.0 \mathrm{ng} / \mathrm{ml}$ by ELISA. Although CA-I is not a specific marker of erythrocytes, CA-I may be used to detect occult blood in canine feces and urine until a specific immunological test kit using antibody for $\mathrm{Hb}$ is developed.
\end{abstract}

Key words: canine feces, carbonic anhydorase isoenzyme I (CA-I), occult blood

\section{Introduction}

In human medicine, chemical [9, 14] and immunological [1, 17] tests for occult blood are currently employed in early screening for hemorrhagic diseases of the intestine, such as tumors or cancer. Immunological tests for occult blood are specific for hemoglobin (Hb) derived from erythrocytes [24]. Chemical tests

(Received 20 October 2005 / Accepted 2 October 2006)

Address corresponding: S. Yamamoto, Laboratory of Immunology, College of Environmental and Health Sciences, Azabu University, 1-17-71

Fuchinobe, Sagamihara, Kanagawa 229-8501, Japan 
for fecal occult blood are sensitive, but false-positive reactions can be induced by the blood present in ingested meat and fish $[12,25]$. In veterinary medicine, including the field of drug safety evaluation, the development of specific immunological tests using anti $\mathrm{Hb}$ antibodies for occult blood in various animals is indispensable. In dogs, a few reports have described the usefulness of immunological tests for fecal occult blood $[10,11]$, but chemical tests are currently used for the detection of fecal occult blood [7]. Because erythrocytes contain both $\mathrm{Hb}$ and carbonic anhydorase isoenzyme I (CA-I) [11] as major proteins, the purification of canine $\mathrm{Hb}$ from lysate and the preparation of antibody for canine $\mathrm{Hb}$ are very difficult. When compared with $\mathrm{Hb}$, it is relatively simple to prepare a specific antibody for canine CA-I.

Although CA is present in the tissues of the intestinal and the urinary organs [20], and small amounts of CA-I are probably secreted into feces and urine, CA-I may be useful for detecting occult blood in various animals until specific immunological tests for occult blood are developed.

This paper describes an enzyme-linked immunosorbent assay (ELISA) for the detection of CA$\mathrm{I}$ as a temporary marker of occult blood in feces and urine from healthy beagle dogs.

\section{Materials and Methods}

\section{Dogs, blood, feces and urine}

Eleven healthy beagle dogs ( 5 males and 6 females; age, 12-13 months) were kept in the experimental animal facilities of the Research Institute of Biosciences at Azabu University (temperature, $20 \pm 2{ }^{\circ} \mathrm{C}$; relative humidity, $50 \pm 10 \% ; 12 / 12$ light/dark cycle $(6: 00-$ 18:00); air exchange occurred 13 times per hour) and were used in this study. The beagle dogs were fed Clea CD-5 dog feed (Clea Japan, Inc., Tokyo, Japan), and were allowed free access to water. Heparinized blood for isolation and quantification of CA-I and feces for determination of CA-I were collected from these dogs. For isolation of CA-I from erythrocytes, heparinized blood was washed 7 times in physiological saline by centrifugation at $1,600 \times \mathrm{g}$ for $10 \mathrm{~min}$. Sedimented erythrocytes were then lysed in distilled water and an equal volume of $0.02 \mathrm{M}$ phosphate buffered saline (PBS; $\mathrm{pH} 7.2)$. Erythrocyte lysate containing CA-I was ob- tained by centrifugation at $1,600 \times \mathrm{g}$ for $10 \mathrm{~min}$. This lysate was mixed with $0.1 \%$ sodium azide and was stored at $-80^{\circ} \mathrm{C}$ until use.

For immunological quantification of fecal CA-I by ELISA, feces samples were treated and stored within 6 $\mathrm{h}$ of collection. One gram of feces was mixed with 1 $\mathrm{ml}$ of distilled water, after which $1 \mathrm{ml}$ of $0.02 \mathrm{M}$ PBS containing $0.2 \%$ sodium azide was added. The supernatant obtained by centrifugation $(1,600 \times \mathrm{g}$ for $10 \mathrm{~min})$ was stored immediately at $-80^{\circ} \mathrm{C}$ until use.

In order to quantify the amount of CA-I in feces from healthy beagle dogs of various ages, feces were collected from 113 beagle dogs (50 males and $63 \mathrm{fe}-$ males; age, 3-24 months), kept in isolators at the Breeding Division of Hongo Beagle Farm, Kitayama Labes Co., Ltd. (Yamaguchi, Japan) at a temperature of $23 \pm 2^{\circ} \mathrm{C}$, a relative humidity of $55 \pm 10 \%$, and a $12 /$ 12 light/dark cycle (6:00-18:00) with air exchange occurring at least 12 times per hour. Dogs were fed a DS-E diet (Oriental Yeast Co., Ltd., Tokyo, Japan), and were allowed free access to water. For immunological quantification of CA-I, feces samples were treated and stored as described above.

In order to quantify the amount of CA-I in urine from healthy beagles dogs, urine was collected by catheter from 55 beagle dogs ( 28 males and 27 females; age, 6-24 months) kept in isolators at the Breeding Company, CSK Co., Ltd., (Nagano, Japan) (44 dogs) and in the experimental animal facilities at Azabu University $(11 \mathrm{dogs})$. Urine was used for both quantification of CA-I by ELISA and detection of hemoglobin by chemical testing. Urine was also mixed with $0.1 \%$ sodium azide and stored at $-80^{\circ} \mathrm{C}$ until use.

All experiments conformed to the Japanese regulations on animal care and use, based on the Guidelines for Animal Experimentation (Japanese Association for Laboratory Animal Science, JALAS, 1987), and were approved by the Institutional Animal Care and Use Committee of CSK Co., Ltd. and the Animal Research Committee of Azabu University.

\section{Isolation of canine CA-I}

Canine CA-I was isolated using the method of Nishita et al. [16]. Briefly, the CA fraction was obtained from lysate of washed canine erythrocytes using the chloroform-ethanol denaturation method, which is used for the preparation of CA in a number of other mammals. 
$\mathrm{Hb}$ was removed as a precipitate and the supernatant was then collected and dialyzed against $10 \mathrm{mM}$ Tris$\mathrm{HCl}$ buffer ( $\mathrm{pH} 8.0)$. CA-I was isolated from the supernatant by liquid chromatography, as described by Funakoshi and Deutsch [6]. For fast protein liquid chromatography (FPLC; Amersham Biosciences, Uppsala, Sweden), a HiLoad 16/10 Q sepharose column (Amersham Biosciences) was used for ion-exchange chromatography, a Mono P HR5/20 column (Amersham Biosciences) was used for chromatofocusing and a Superdex 200 16/60 column (Amersham Biosciences) was used for gel filtration. CA enzyme activity and hemoglobin content of each fraction on FPLC were detected by p-nitrophenyl acetate [4] and 2,2'-azino-di-(3-ethylbenzthiazoline-6sulfonic acid) (ABTS; Zymed Laboratories, South San Francisco, CA, USA), respectively.

\section{Anti canine CA-I antibody}

A New Zealand rabbit was initially immunized subcutaneously with $1 \mathrm{ml}$ of CA-I emulsion prepared with Freund's complete adjuvant. The rabbit subsequently received ten further injections of CA-I solution alone. Serum was collected at 7 days after the final immunization and was stored at $-80^{\circ} \mathrm{C}$ until needed.

$\mathrm{IgG}$ antibody was obtained from this antiserum by affinity chromatography on a Protein A column (Amersham Biosciences) [8]. Subsequently, specific IgG antibody against canine CA-I was isolated by affinity chromatography using a HiTrap NHS-activated HP gel coupled with canine CA-I. The specific IgG antibody to canine CA-I was used for ELISA. Peroxidase (Sigma-Aldrich Fine Chemical, St Louis, Mo, USA)-conjugated IgG antibody was prepared by the method of Nakane and Kawaoi [15]. This peroxidaseconjugated IgG antibody was used for ELISA.

\section{Quantification of proteins}

Isolated CA-I was quantified by the method of Bradford [3] using Coomassie brilliant blue G-250. Rabbit anti canine CA-I IgG antibody was quantified using a Bio-Rad Protein Assay Kit (Bio-Rad Laboratories, Hercules, CA, USA).

Sodium dodecyl sulfate-polyacrylamide gel electrophoresis (SDS-PAGE) and western blotting

SDS-PAGE and western blotting were performed us- ing the methods of Laemmli [13] and Towbin et al. [23], respectively. After SDS-PAGE for isolated CA-I, the gels were stained with Coomassie brilliant blue R250.

The specificity of the rabbit anti canine CA-I IgG antibody was confirmed by western blotting analysis followed by SDS-PAGE.

\section{ELISA for CA-I}

ELISA for CA-I was carried out using the sandwich method described by Yamamoto et al. [26]. Rabbit anti canine CA-I IgG antibody was adjusted with 0.05 M sodium hydrogencarbonate buffer ( $\mathrm{pH} 9.6$ ) to $10 \mu \mathrm{g} /$ $\mathrm{ml}$ for use as the coating antibody. The coating antibody $\left(100 \mu \mathrm{l} /\right.$ well) was incubated at $37^{\circ} \mathrm{C}$ for $1 \mathrm{~h}$ in an ELISA plate (Nalge Nunc International, Rochester, NY, USA). Next, $1 \%$ bovine serum albumin (BSA; Wako Chemical Co., Ltd., Osaka, Japan) in 0.05 M sodium hydrogencarbonate buffer ( $\mathrm{pH}$ 9.6) was added to all the wells at $300 \mu \mathrm{l} /$ well to block any unadsorbed binding sites $\left(4^{\circ} \mathrm{C}\right.$, overnight). After washing, a known concentration of CA-I or samples were added at $100 \mu \mathrm{l} /$ well and the plates were incubated at $37^{\circ} \mathrm{C}$ for $1 \mathrm{~h}$. The peroxidase-conjugated rabbit anti canine CA-I IgG antibody, adjusted with PBS to $2.5 \mu \mathrm{g} / \mathrm{ml}$, was added to all the wells at $100 \mu \mathrm{l} /$ well and was allowed to react at $37^{\circ} \mathrm{C}$ for $1 \mathrm{~h}$. Substrate at $0.05 \%$ in $0.05 \mathrm{M}$ citrate buffer ( $\mathrm{pH} 4.2$ ) was added at $100 \mu \mathrm{l} /$ well. The results were determined by measuring the absorbance at 415 $\mathrm{nm}$ with an immunoplate reader.

\section{Experimental models for detection of CA-I in feces}

Three healthy beagle dogs each received 5 or $10 \mathrm{ml}$ of autologous blood infused from a syringe via a catheter into the stomach. After 1 week, the same 3 healthy dogs each received 1 or $5 \mathrm{ml}$ of autologous blood similarly infused into the ascending colon. Samples were collected from the first to the third spontaneous defecations for detection of CA-I. Feces obtained from these dogs prior to infusion of autologous blood were used as controls. Feces $(1 \mathrm{~g})$ were treated as described above.

In order to asses changes in CA-I antigenicity in feces, $1 \mathrm{~g}$ of feces from 2 healthy dogs was mixed with $100 \mu \mathrm{l}$ of blood and was allowed to stand at room temperature for $12 \mathrm{~h}$. CA-I was then extracted as above, and its antigenicity was assessed by ELISA.

Chemical test for urinary occult blood 
Occult blood in urine was detected using Multistix SG-L (Distributed by Sankyo Co., Ltd., Tokyo, Japan).

\section{Results}

Isolation of canine CA-I and anti canine CA-I antibody CA-I was isolated from the lysate of canine erythrocytes by liquid chromatography using FPLC (Fig. 1A). In western blotting, anti canine CA-I antibody formed a single band with isolated canine CA-I and with a 30$\mathrm{kDa}$ protein in lysate of canine erythrocytes (Fig. 1B).

\section{Concentrations of CA-I in blood}

As shown in Table 1, CA-I concentrations in blood from 3 apparently healthy beagle dogs ranged from 1,047 to $1,150 \mu \mathrm{g} / \mathrm{ml}$ blood.

\section{Antigenicity of CA-I}

The antigenicity of canine CA-I stored in feces at room temperature for $12 \mathrm{~h}$ did not change (Table 2).

Concentrations of CA-I in feces from healthy dogs

The fecal CA-I concentrations in 113 healthy beagle dogs of various ages are shown in Table 3. Fecal CA-I concentrations ranged from 4.3 to $16.7 \mathrm{ng} / \mathrm{g}$ feces (mean; $7.0 \pm 2.9 \mathrm{ng} / \mathrm{g}$ feces).

Detection of CA-I in feces in experimental models of digestive tract bleeding

The fecal CA-I concentrations of dogs that received intragastric infusion of autologus blood were very low (Table 4). However, the fecal CA-I concentrations of the dogs that received infusion of autologous blood (5 $\mathrm{ml}$ ) into the ascending colon were very high, as shown in Table 4.

\section{Concentrations of CA-I in urine}

Urinary samples from 44 of 55 dogs were negative by chemical testing (detectable limit $150 \mathrm{ng}$ hemoglobin/ml). As shown in Table 5, CA-I concentrations in the negative urinary samples ranged from 1.8 to 12.6 $\mathrm{ng} / \mathrm{ml}$ (mean; $6.9 \pm 5.4 \mathrm{ng} / \mathrm{ml}$ ) by ELISA. On the other hand, urinary samples from the other $11 \mathrm{dogs}$ were positive by chemical testing. The CA-I concentrations of 6 urinary samples that were $2+$ on chemical testing were $41.2-98.0 \mathrm{ng} / \mathrm{ml}$, while the CA-I concentrations of 5 samples that were $3+$ on chemical testing

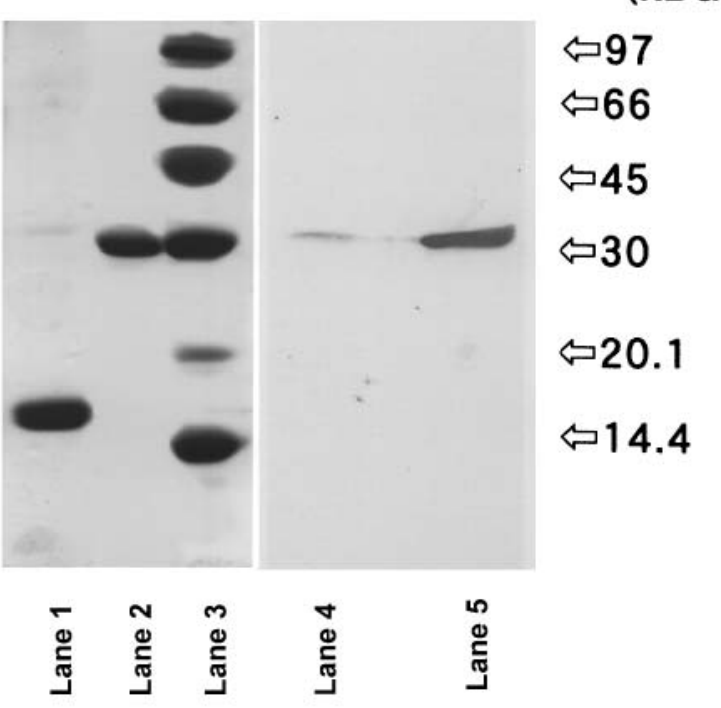

\section{$\begin{array}{ll}\text { A. SDS-PAGE } & \text { B. Western Blot }\end{array}$}

Fig. 1. Analysis of isolated canine CA-I by SDS-PAGE and anti canine CA-I antibody by western blot. A: SDSPAGE Lane 1: lysate of canine erythrocytes; Lane 2: isolated canine CA-I; Lane 3: molecular weight marker in $\mathrm{kDa}$ (Coomassie brilliant blue R-250 stain). B: Western blot Lane 4: lysate of canine erythrocytes; Lane 5: isolated canine CA-I.

Table 1. Concentrations of CA-I in blood from healthy experimental beagle dogs by ELISA

\begin{tabular}{lccc}
\hline Dogs & $\begin{array}{c}\text { Concentration of } \\
\text { CA-I }(\mu \mathrm{g} / \mathrm{ml})\end{array}$ & $\begin{array}{c}\text { Erythrocyte } \\
\text { counts }(/ \mu \mathrm{l})\end{array}$ & Hematocrit value (\%) \\
\hline 1 & 1,150 & $7,500,000$ & 52 \\
2 & 1,047 & $7,900,000$ & 49 \\
3 & 1,062 & $8,210,000$ & 53 \\
\hline
\end{tabular}

Table 2. In vitro changes in antigenicity of canine CA-I $(\mathrm{ng} / \mathrm{g})$ in feces

\begin{tabular}{ccc}
\hline & \multicolumn{2}{c}{ Feces } \\
\cline { 2 - 3 } Time after mixing & 1 & 2 \\
\hline Immediately & 1,535 & 2,115 \\
$4 \mathrm{~h}$ & 1,730 & 1,960 \\
$8 \mathrm{~h}$ & 1,225 & 2,200 \\
$12 \mathrm{~h}$ & 1,620 & 2,280 \\
\hline
\end{tabular}

Faecal materials $(1 \mathrm{~g})$ were mixed with blood $(0.1 \mathrm{ml})$ and allowed to stand at room temperature for $12 \mathrm{~h}$. 
Table 3. Fecal CA-I concentrations (ng/g faeces) in 113 healthy experimental beagle dogs by ELISA

\begin{tabular}{lrrrrrrr}
\hline & \multicolumn{7}{c}{ Months - old } \\
\cline { 2 - 8 } & \multicolumn{1}{c}{3} & \multicolumn{1}{c}{6} & \multicolumn{1}{c}{9} & 12 & 18 & 24 & total \\
\hline Dogs & 20 & 20 & 20 & 20 & 20 & 13 & 113 \\
Means & 7.9 & 6.7 & 8.3 & 5.7 & 6.9 & 6.3 & 7.0 \\
Maximum & 16.6 & 13.4 & 16.7 & 8.4 & 9.9 & 9.0 & 16.7 \\
Minimum & 4.6 & 4.4 & 4.7 & 4.3 & 4.7 & 4.5 & 4.3 \\
SD & 3.1 & 2.5 & 4.0 & 1.1 & 3.0 & 1.4 & 2.9 \\
\hline
\end{tabular}

Table 4. Concentrations of CA-I(ng/g) in canine feces by ELISA after infusion of autologous blood

\begin{tabular}{cccccc}
\hline & \multicolumn{2}{c}{ Stomach } & & \multicolumn{2}{c}{ Ascending colon } \\
\cline { 2 - 3 } \cline { 5 - 6 } Feces sample $^{\mathrm{n}}$ & $5 \mathrm{ml}$ (blood) & $10 \mathrm{ml}$ (blood) & & $1 \mathrm{ml}$ (blood) & 5 ml(blood) \\
\hline Control $^{\mathrm{b}}$ & 9 & 7 & & 12 & 19 \\
$1^{\text {c }}$ & 11 & 8 & & 30 & 2,950 \\
2 & 21 & 49 & & 44 & 1,450 \\
3 & 7 & 28 & & 12 & 2,150 \\
\hline
\end{tabular}

aFeces $(1 \mathrm{~g})$ was dissolved in distilled water $(1 \mathrm{ml})$, mixed with a two-fold concentration of PBS (1 ml) and centrifuged. Supernatant was used for ELISA. ${ }^{b}$ Feces samples collected prior to infusion of blood into stomach or ascending colon were used as controls. ${ }^{\mathrm{c} N u m b e r}$ of defecation after infusion of blood into stomach or ascending colon.

were $173.0-525.0 \mathrm{ng} / \mathrm{ml}$ by ELISA (Table 5).

\section{Discussion}

In human medicine, chemical tests for fecal occult blood have largely been replaced by immunological methods [19]. However, the development of useful methods that allow specific detection of internal bleeding in dogs and another animals remains at an early stage.

Although we have previously reported the usefulness of immunological tests using specific anti canine $\mathrm{Hb}$ antibody for occult blood in dogs $[10,11]$, the preparation of anti canine $\mathrm{Hb}$ antibody is currently very difficult. Therefore, nonspecific chemical tests [12, 25] are generally employed to detect fecal occult blood in dogs, and these techniques are still used in for a variety of purposes, such as drug safety evaluation, or in veterinary clinics.

CA-I is not a specific marker of erythrocytes, as it is present in the tissues of the intestinal and urinary organs [20] and it may be secreted from these organs into
Table 5. The relationship between chemical tests for occult blood and CA-I concentrations $(\mathrm{ng} / \mathrm{ml})$ of urine in experimental beagle dogs

\begin{tabular}{lccc}
\hline Chemical test (samples) & \multicolumn{2}{c}{ CA-I concentrations $(\mathrm{ng} / \mathrm{ml})$} \\
\hline $\begin{array}{l}\text { Negative (44) } \\
\text { Positive (11) }\end{array}$ & $1.8-12.6$ & (mean 6.9 \pm 5.4$)$ \\
2+ positive (6) & $41.2-98.0$ & $($ mean $69.4 \pm 26.5)$ \\
3+ positive (5) & $173.0-525.0$ & (mean 335.0 \pm 132.7$)$ \\
\hline
\end{tabular}

their respective tracts. Unfortunately, it is impossible to determine the origin of CA-I. However, CA-I may be used to detect occult blood in canine feces until a specific immunological test kit using antibody for $\mathrm{Hb}$ is developed. This is because fecal CA-I concentrations in healthy dogs were very low, while fecal CA-I concentrations in dogs that received infusion of autologous blood into the ascending colon were found to be very high. When 3 dogs were infused $1 \mathrm{ml}$ of autologous blood, CA-I was not detected in feces, probably because feces containing the infused blood were not collected in test samples. Detection of fecal CA-I would 
thus be useful for identifying dogs with hemorrhaging of the large intestine.

The antigenicity of human $\mathrm{Hb}$ changes as a result of digestive enzymes or fecal bacteria [5]. However, when feces samples were mixed with blood and allowed to stand at room temperature for $12 \mathrm{~h}$, the reactivity of canine CA-I did not change. Consequently, CA-I in feces may be used as an antigen for immunological tests.

Physiological bleeding into the intestine is seen even in healthy humans [2] and dogs [11]. Such internal bleeding should be carefully considered in the clinical application of immunological tests for fecal occult blood in dogs [10]. Eleven of 58 urinary samples from apparently healthy beagle dogs were positive by chemical testing and showed markedly increased CA-I by ELISA. This is thought to have been due to scratching of the ureter mucous membrane when the tube was inserted to collect urine.

Although sensitive methods, such as ELISA, are required in the quantification of CA-I in dogs, CA-I concentrations are a useful temporary marker for occult blood. In the future, it will be necessary to develop quantitative methods for occult blood using $\mathrm{Hb}$ as a specific marker.

\section{Acknowledgments}

We thank CSK Co., Ltd., for the supply of canine urine.

\section{References}

1. Adams, E.C. and Layman, K.M. 1974. Immunochemical confirmation of gastrointestinal bleeding. Ann. Clin. Lab. Sci. 4: 343-349.

2. Ahlquist, D.A., McGill, D.B., Schwartz, S., Taylor, W.F., Ellefson, M., and Owen, R.A. 1984. Hemo-Quant, a new quantitative assay for fecal hemoglobin: comparison with Hemoccult. Ann. Intern. Med. 101: 297-302.

3. Bradford, M.M. 1976. A rapid and sensitive method for the quantitation of microgram quantities of protein utilizing the principle of protein-dye binding. Anal. Biochem. 72: 248-254.

4. Demir, N., Demir, Y., and Nadaroglu, H. 2001. Carbonic anhydrase from bovine bone. Prep. Biochem. Biotechnol. 31: 33-47.

5. Francis, R.T.Jr., Booth, J.W., and Becker, R.R. 1985. Uptake of iron from hemoglobin and the haptoglobinhemoglobin complex by hemolytic bacteria. Int. J. Biochem.
17: 767-773.

6. Funakoshi, S. and Deutsch, H.F. 1963. Human carbonic anhydrases. I. Isolation and demonstration of isoenymes in erythrocytes. J. Biol. Chem. 243: 6474-6481.

7. Gilson, S.D., Parker, B.B., and Twedt, D.C. 1990. Evaluation of two commercial test kits for detection of occult blood in feces of dogs. Am. J. Vet. Res. 51: 1385-1387.

8. Gousdawaard, J., Van der Donk, J.A., Noordzij, A., Van Dam, R.H., and Vaerman, J-P. 1978. Protein A reactivity of various mammalian immunoglobulins. Scand. J. Immunol. 8:21-28.

9. Greegor, D.H. 1967. Diagnosis of large-bowel cancer in the asymptomatic patient. J. Am. Med. Assoc. 18: 943-945.

10. Jinbo, T., Shinmura, R., Shida, T., Shimizu, M., Honda, M., Hayashi, S., Iguchi, K., and Yamamoto, S. 1997. Experimental detection of canine hemoglobin (occult blood) in canine faeces by reversed passive latex agglutination. Vet. Res. Commun. 21: 347-353.

11. Jinbo, T., Shimizu, M., Hayashi, S., Shida, T., Sakamoto, T., Kitao, S., and Yamamoto, S. 1998. Immunological determination of faecal hemoglobin concentrations in dogs. Vet. Res. Commun. 22: 193-201.

12. Kachmar, J.F. 1970. Tests for occult blood. pp. 279-282. In: Fundamentals of Clinical Chemistry (Tietz, N.W. ed.) W.B. Saunders, Philadelphia.

13. Laemmli, U.K. 1970. Cleavage of structural proteins during the assembly of the head of bacteriophage T4. Nature 227: 680-685.

14. Macrae, F.A. and St John, D.J.B. 1982. Relationship between patterns of bleeding and hemoccult sensitivity in patients with colorectal cancers or adenomas. Gastroenterology 82: 891-898.

15. Nakane, P.K. and Kawaoi, A. 1974. Peroxidase-labelled antibody. A new method of conjugation. J. Histochem. Cytochem. 22: 1084-1091.

16. Nishita, T., Kondo, H., Ishida, S., Ochiai, H., and Asari, M. 2000. Isolation and measurement of carbonic anhydrase isoenzymes in erythrocytes of dogs. Am. J. Vet. Res. 61: 387-392

17. Saito, H., Tsuchida, S., Fujita, H., Fukuda, S., Aisawa, T., Munakata, A., and Yoshida, Y. 1982. An immunological test for fecal occult blood by counter immunoelectrophoresis. False-positive reaction due to nonhemoglobin proteins in the tests with an anti-crude hemoglobin antibody. Jpn. J. Gastroenterol. 79: 1944-1949 (in Japanese with English summary).

18. Saito, H., Tsuchida, S., Kakizaki, R., Aizawa, N., Munakata, A., and Yoshida, Y. 1985. An immunological fecal occult blood test for mass screening of colorectal cancer. Basic Pharmacology and Therapeutics (Suppl) 13: 39-44 (in Japanese).

19. Simon, J.B. 1985. Occult blood screening for colorectal carcinoma: a critical review. Gastroenterology 88: 820-837.

20. Spicer, S.S., Sens, M.A., and Tashian, R.E. 1982. Immunocytochemical demonstration of carbonic anhydrase in human epithelial cells. J. Histochem. Cytochem. 30: 864-873.

21. St John, D.J.B. and Young, G.P. 1978. Evaluation of radiochromium blood loss studies in unexplained iron- 
deficiency anemia. Aust. NZ. J. Med. 8: 121-126.

22. Stroehlein, J.R., Fairbanks, V.F., and Mcgill, D.B. 1976. Hemoccult detection of fecal occult blood quantitated by radioassay. Am. J. Dig. Dis. 21: 841-844.

23. Towbin, H., Staehelin, T., and Gordon, J. 1979. Electrophoretic transfer of proteins from polyacrylamide gels to nitrocellulose sheets: procedure and some applications. Proc. Natl. Acad. Sci. USA 76: 4350-4354.

24. Turunen, M.J., Liewendahl, K., Partanen, P., and Adlercreutz,
H. 1984. Immunological detection of faecal occult blood in colorectal cancer. Br. J. Cancer. 49: 141-148.

25. Uchida, K., Matsuse, R., Miyachi, N., and Tomita, S. 1990. Immunological fecal occult blood test. Jpn. J. Clin. Med. (Suppl) 48: 1276-1285 (in Japanese).

26. Yamamoto, S., Tagata, K., Nagahata, H., Ishikawa, Y., Morimatsu, M., and Naiki, M. 1992. Isolation of canine Creactive protein and characterization of its properties. Vet. Immunol. Immunopathol. 30: 329-339. 